\title{
1995 CIF/IFC Gold Medal Winners
}

\section{Maritime Forest Ranger \\ School \\ Kimberly Cole}

Ms. Kimberly Cole was the 1995 winner of the CIF/IFC Gold Medal at the Maritime Forest Ranger School. Kim is from Sackville, NB. Prior to coming to MFRS, she worked for several summers for J. D. Irving Ltd. in various aspects of forest management. Kim attended both the University of New Brunswick and Mount Allison University.

Kim was an excellent student, graduating with Honours. She won the Norvin Smith Crawford Award for the highest standing in the woodlot management and the Graduor Prize for the second highest stand in fieldwork for the year at MFRS. Kim was also involved with student affairs as President of the Student Council.

\section{University of New Brunswick Mark Jelley}

Mark Jelley, from Summerside, PEI, is the CIF Gold Medal winner this year at UNB's Faculty of Forestry and Environmental Management. Besides being very active in varsity sports and music, Mark has been on the Dean's List every year. During his university career, he has been involved in such groups as the Forest Engineering Student Association and the Forest Engineering Undergraduate Society. Mark has also been heavily involved in the university residence system. He has been elected to the Executive of Neville House Committee, member of the Residence Food and Orientation Committees, and most importantly has been an Academic Resource Person (A.R.P.). In his capacity as an A.R.P., he has provided counsel, advise, and direction to fellow students. Mark has been a most deserving recipient of many awards and scholarships and brings credit to the CIF Gold Medal.

\section{Cégep de Chicoutimi Caroline Durand}

Madame Caroline Durand, étudiante de troisième année en aménagement forestier a retenu notre attention surtout pour son implication au sein du département en plus d'avoir un dossier académique fort valable (organisation d'activités, collecte de fonds, leadership). Madame Durand a su faire sa marque au Cégep de Chicoutimi.

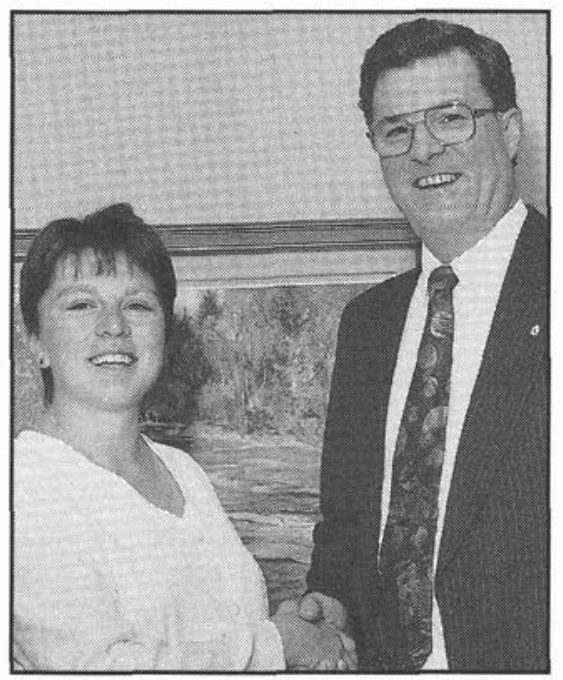

Kimberly Cole with Hap Oldham

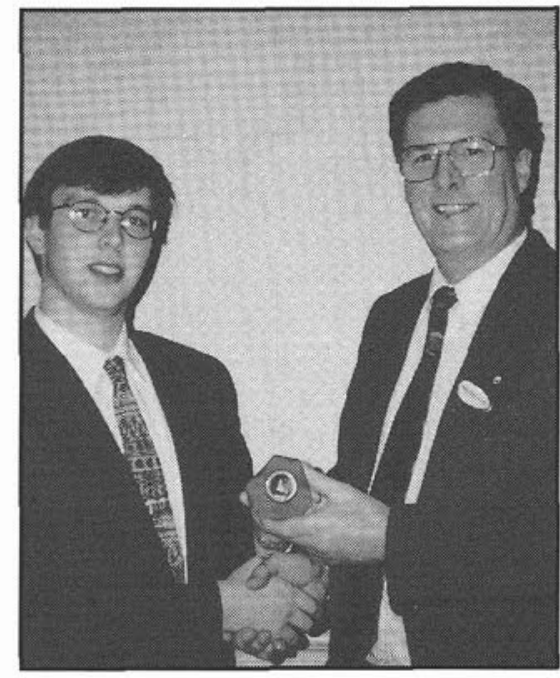

Mark Jelly with Hap Oldham

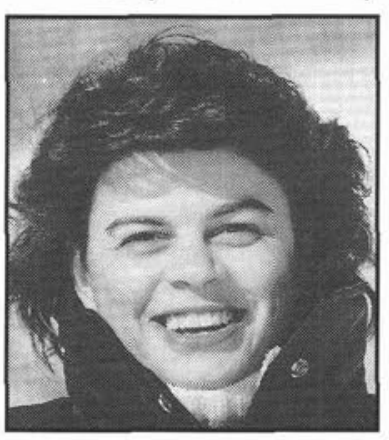

Caroline Durand

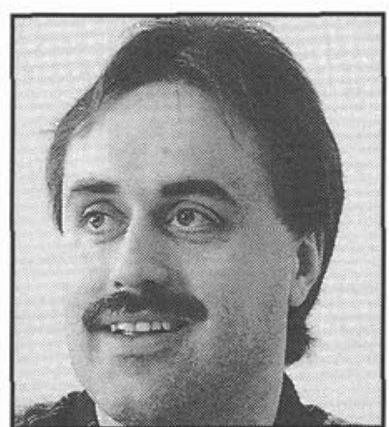

Marc St-Gelais

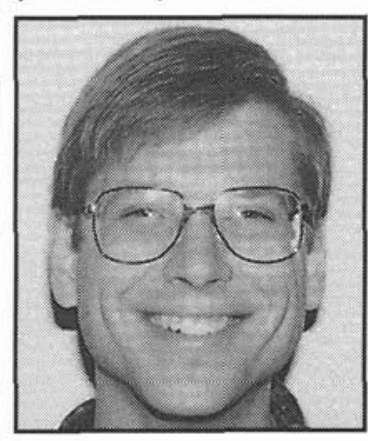

Ron Cornies

\section{Cégep de Baie-Comeau \\ Marc St-Gelais}

En 1993, M. Marc St-Gelais s'est inscrit au programme d'étude en aménagement forestier au Cégep de BaieComeau. Il a choisi de participer aux stages alternance travail-études. Il a complété ses stages en participant aux travaux du Ministère des Ressources naturelles (Unité de gestion de Forestville) et de la Scierie des Outardes. Marc a fait un retour aux études après avoir travaillé dans le domaine de l'alimentation. Propriétaire d'une terre boisée, il voulait se donner une formation et obtenir un diplôme démontrant ses compétences en foresterie. Marc a complété son cours en trois ans. Il est récipiendaire de la médaille de l'Institut forestier du Canada, mais aussi d'une bourse de l'ordre des technologues professionnels et d'une bourse de l'Association Canadienne des pâtes et papiers.

\section{Sault College of Applied Arts and Technology \\ Ron Cornies}

Ron is completing his graduate year of studies in Forestry at Sault College of Applied Arts and Technology where he has continued developing outdoor skills and is an active student representative at staff meetings and on Academic Council. An avid interest in the outdoors has led him to spend time working in the field as a sampling technician for the Canadian Forest Service and to organize and lead wilderness camping excursions for Silver Lake Mennonite Camp. He has also worked as an Assistant Manager for Black's Cameras and studied at McMaster University where he earned a B.A. in history. After graduation Ron hopes to spend some time mountain biking before he pursues an interest in silviculture either on the job or as a student.

\section{University of British Columbia Naomi Wills}

Hailing from the North Okanagan, Naomi Wills spent many years at the local College. After 2 years of Commerce, one of Arts, and one of Science she made the big move to UVIC for a year of Environmental Studies and Geography. 


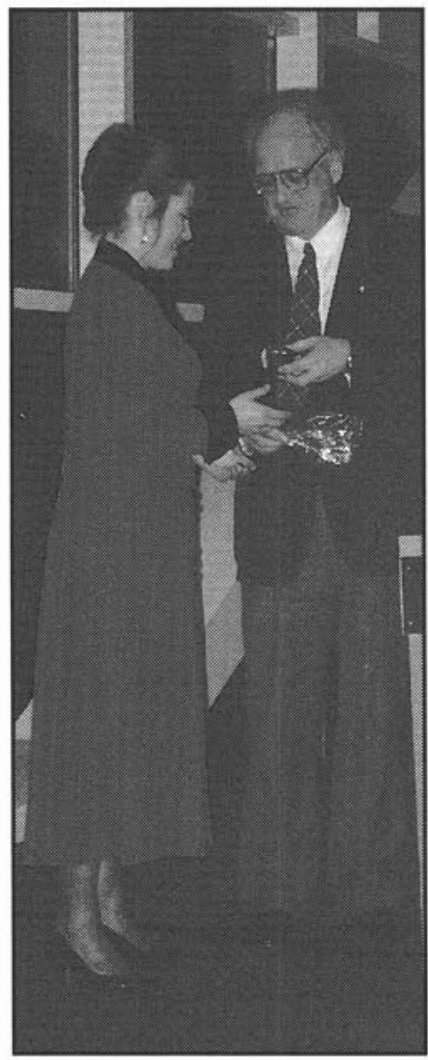

Naomi Wills and John Barker

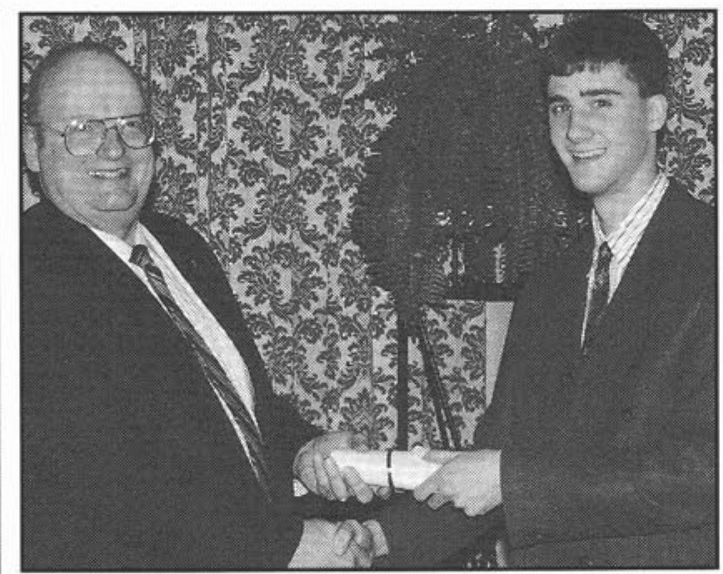

Dr. J. Beck and Dave Stepnisky

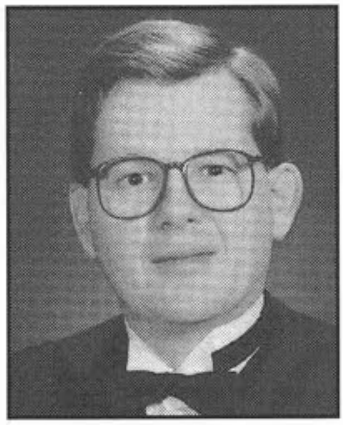

Bob Decker

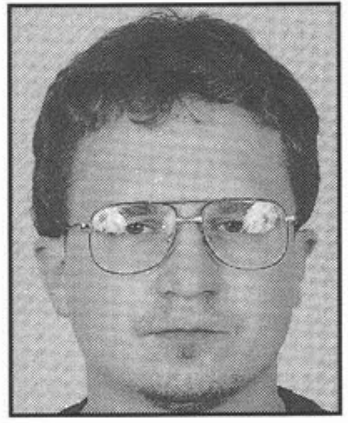

Dean Hrycan
School at this time did not seem to be the answer, so she worked and travelled for awhile to Southeast Asia, Australia, and New Zealand.

This was the time that her true destiny came to her. "Forestry - you haven't tried Forestry", a little voice said. Without further ado, she enrolled at her final stop, UBC. During her time here Naomi spent much time being active with UBC Intramurals, Logger's Sports and the Forestry Undergraduate Society. She started off as theWomen's Sports Rep. followed by the Presidency. As well, this 27 year old scholarship student was a representative on the Task Force on Professional Forestry Curricula for 2 years.

After 2 summers with Riverside Forest Products in Armstrong, Naomi will be working an 8 month job with West Fraser in Quesnel. Following a few months of travelling and looking at Forestry opportunities in Europe, she will be looking for work in BC, and would eventually like to be involved in Forest Industry and First Nations interactions.

\section{University of Alberta Dave Stepnisky}

The recipient of the CIF Schlich
Memorial Fund award for 1996 is Dave Stepnisky. Dave has attained high academic standing during his five years as a student. In addition, his involvement in forestry activities during that period have been unsurpassed: President of the Forest Society in 1995/96, Yearbook Coordinator in 1994/95, Head Teaching Assistant for Dendrology, and Senior Teaching Assistant in Forest Wildlife. His leadership and ability to work with students, staff, and professionals have enabled him to play a key role in the Forestry Program.

Dave has considerable experience in forest biology. He was employed with the Canadian Wildlife Service as a biological technician, he worked at the University in a wildlife research project, and most recently was employed by Weyerhaeuser Canada in Prince Albert. Upon graduation Dave will be joining Alberta Fish and Wildlife as a non-game biologist in wildlife conservation. As the new class representative for the forestry alumni, he plans to continue working with foresters for many years to come.

Hockey, cross country skiing, photography, and bird-watching are a few of the many activities that he enjoys in his spare time. Dave's love for the forest and faith in people will always make him a valued member of the forestry community.

\section{Bob Decker}

The 1996 winner of the CIF gold medal, Bob Decker, embodies the traits desired in a modern integrated resource manager. Raised in the Northwest Territories, he developed a keen interest in wildlife while in High School. Upon graduation he entered the University of Alberta, where he completed an undergraduate degree in Zoology. Shortly thereafter he began 16 years of service in the Northwest Territories Department of Renewable Resources where he worked as a wildlife technician, wildlife biologist, and resource development officer. He returned to the University in 1993 where he established himself as a top student in the Program, winning five major scholarships and awards, including an NSERC post-graduate award.

Bob's goal is to use his multidisciplinary background as a decisionmaker in the management of wildlife and other forest resources. To that end he has begun an MSc. program with Dr. Victor Lieffers in which he will be examining mixedwood management in the boreal forest.

Married for 12 years, and recently a father for the first time, Bob occasionally finds time for his other interests: hunting, photography, skiing and flying.

\section{Northern Alberta Institute of Technology \\ Dean Hrycun}

Dean Hrycun is the recipient of the CIF Gold Medal in the NAIT Forest Technology program at the Environmental Training Centre for 1995-96. Dean attained the top academic standing in both years in the Forest Technology program. He was on the honor roll both years. Dean served as president of the student council during his two years in the program. He has been active in various sports: floor hockey, baseball, bowling and volleyball. He was responsible for organizing the Bull-of-the Woods competition in the second year. For relaxation Dean plays the guitar and the harmonica and writes his own music. Originally from Lamont, Alberta, he will be returning to Mackenzie, BC to work with Finlay Forest Industries on road and block layout. 


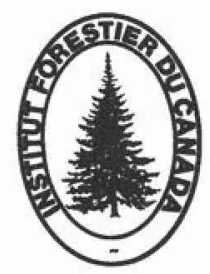

\section{8th Annual Meeting of the Canadian Institute of Forestry THUNDER BAY, ONTARIO}

\section{Global Influences - Local Realities A Cross-Country Check-up}

August 18-22, 1996

$\mathrm{T}$ 'HE CITY OF THUNDER BAY, nestled beside the Nor'Wester range and spectacular Lake Superior, will host this year's conference. Here, you will gaze out upon the endless blue of an inland sea...then look up at the sungilded cliffs of the Nor'Wester range and into the deep green mystery of the boreal forest.

Home to over 120,000 residents, Thunder Bay owes its development to its extensive natural resources, from the early days as a fur trade centre to later growth in forestry, mining and shipping industries.

Thunder Bay has been hosting conferences since 1815 when the great rendezvous attracted voyageurs, native guides and the Scottish partners of the North West Company.

HAMPCO '96 is proud to offer four plenary sessions supported by a strong component of technical sessions and five field workshops addressing the theme Global Influences - Local Realities - A Cross-Country Check-up. Field workshops will explore four timely subthemes which will continue to unfold in the subsequent plenary and concurrent sessions.

A highlight of the conference will include a one-day meeting with the 7 th North American Caribou Conference. This day will provide a unique forum to exchange information on woodland caribou and gain insight into caribou management issues.

In addition to the professional value of attending this exciting conference, the planning committee has arranged for plenty of opportunity to experience Thunder Bay's famous hospitality and scenery. We are striving to ensure you will receive an

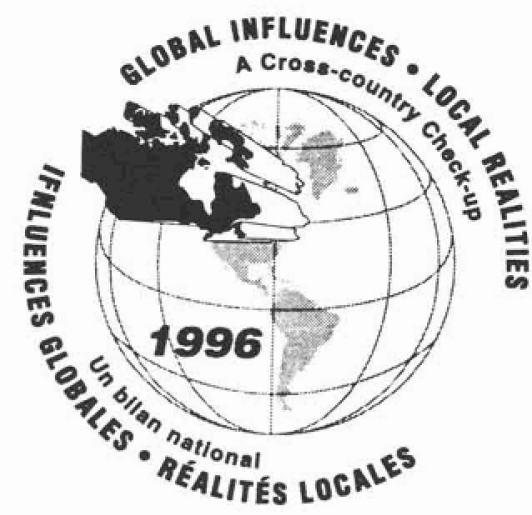

excellent value for your convention dollar.

From the welcoming icebreaker to the banquet at historic Old Fort William, you will understand why Thunder Bay has been a meeting place for almost 200 years.

Matsy Kenney and Laurie McCulligh, Co-Chairs of the Annual Meeting

\section{Global Influences - Local Realities A Cross-country Check-up}

The conference will showcase advanced and innovative forest management techniques from northwestern Ontario and Canada. Conference sub-themes are:

\section{Certification of Forests}

A review of the circumstances that have catalyzed the various certification schemes and a national picture of different processes and experiences.

\section{Model/Demonstration Forests}

Testing new techniques and paradigms in a very public way are key elements of demonstration forests. Updates from specific model and demonstration forests will be discussed in sessions.

\section{Ecosystem Management}

Hear and see how managers address biodiversity and ecosystem productivity across a wide range of scales.

\section{Protected Areas}

A summary of recent initiatives in Canada supported by interesting accomplishments in creating, managing, and using protected areas.

Field workshops, representing each of the four sub-themes, will begin our meeting in Thunder Bay. 


\title{
A Message From The Mayor
}

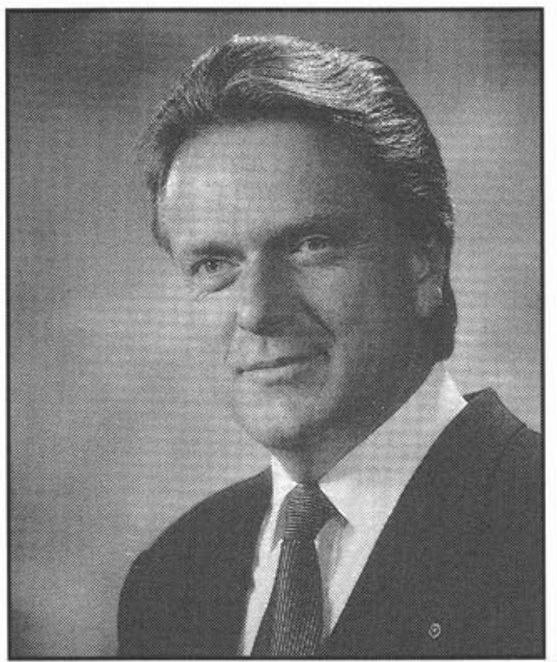

Welcome to Thunder Bay for the 88th Annual Canadian Institute of Forestry Meeting, August 18 to 22, 1996. I wish to thank the Institute for selecting Thunder Bay for this important meeting and scientific conference and the local organizers for all their hard work.

In Thunder Bay, we truly have something for everyone - from our spectacular landscape, to the world's largest reconstructed fur trading post at Old Fort William, to the inspiring Terry Fox Monument, to some of the world's best acoustics at the Thunder Bay Community Auditorium, to a wide variety of shops and restaurants. And that's just a sampling of all we have to offer in this unique city on the shores of Lake Superior. Enjoy your stay in the City we are proud to call Superior by Nature.

On behalf of City Council and the citizens of Thunder Bay, all the best for a successful and enjoyable meeting.

Sincerely,

David Hamilton,

Mayor, City of Thunder Bay

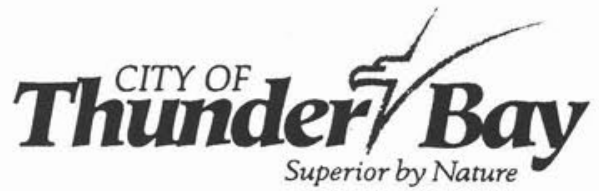

\section{Registration Information}

\begin{abstract}
Hotels
The Valhalla Inn is the Host Hotel and is conveniently located at the intersection of the Trans-Canada Highway and Highway 61 to the United States, with direct access to Thunder Bay's Major streets, business district and shopping centres. The Valhalla Inn provides complimentary limousine service to Thunder Bay International Airport, just 5 minutes away. All plenary and concurrent sessions will be held at the Valhalla Inn.
\end{abstract}

Please quote Registration No. G3630 when making reservations.

Telephone: 1-800-964-1121

Fax:

(807) 475-4723

Rate:

$\$ 79.95$ (single or double)

\section{Travel}

Air Canada is an official carrier for the national meeting. For special convention fares, quote Event No. CV961005. Bearskin Airlines (a regional carrier) is also offering special conference rates. Quote Tour Code CIF0896JV.

\section{Child Care Services}

Day care facilities are available on Lakehead University Campus.

Other hotels are also located within the vicinity.

Airlane Hotel

Telephone: 1-800-465-5003

Best Western (Crossroads)

Victoria Inn

Telephone: 1-800-528-7234

Telephone: 1-800-387-3331

Comfort Inn

Telephone: 1-800-228-5150

Lakehead University

Telephone: (807) 343-8779

Confederation College

Telephone: (807) 475-6383

are also making rooms available to conference delegates.

\section{Registration}

Delegate program $\$ 295$ before July 1st, 1996 (add \$50 after this date). This includes icebreaker, field workshops, Awards luncheon, an historic banquet, all scheduled breakfasts (except Alumni), lunches, and all plenary and concurrent sessions.

Student registration is $\$ 80$ and includes all of the above events.

Companion program $\$ 150$ prior to July 1st, 1996 (add \$20 after this date). In addition to a special companions' program, registrants fee includes icebreaker, Awards luncheon, an historic banquet, all scheduled breakfasts (except Alumni), lunches, and all plenary and concurrent sessions. Field workshops are an additional $\$ 40$.

Daily rates:

August 19, $1996 \quad \$ 75$

August $20 \& 22,1996 \$ 75$

August 21, $1996 \quad \$ 150$

For more information or to register contact: HAMPCO '96 c/o Paul Charrette, Faculty of Forestry, Lakehead University, 955 Oliver Road, Thunder Bay, Ontario P7B 5E1

Fax: (807) 343-8116

Phone: (807) 343-8502 